\title{
Hypospadias treatment by tubulated pedicled preputial island flap according to the DUCKETT technique: single-center experience in sub-Saharan Africa
}

\author{
Modou Ndiaye ${ }^{1 *} \mathbb{C}$, Yaya Sow ${ }^{2}$, Alioune Sarr ${ }^{2}$, Amath Thiam ${ }^{5}$, Samba Thiapato Faye ${ }^{3}$, Ndiaga Seck Ndour², \\ Babacar Sine ${ }^{2}$, Cyrille Zé-Ondo², Ousmane Sow², Abdoulaye Ndiath², Aboubacar Traore ${ }^{5}$, \\ Ndeye Aissatou Bagayogo ${ }^{4}$, Boubacar Fall ${ }^{5}$, Babacar Diao², Papa Ahmed Fall ${ }^{1}$ and Alain Khassim Ndoye ${ }^{2}$
}

\begin{abstract}
Background: Hypospadias is the second most frequent congenital condition in boys after cryptorchidism, with an incidence of $0.3-0.7 \%$ compared to 2-4\% for cryptorchidism. Since the 1980s, single-stage operations, such as the one described by Duckett, have been adopted by some authors. To assess the results of hypospadias surgery by tubed pedicled preputial island flap (DUCKETT's procedure) in a West African reference hospital.

Methods: This is a retrospective and descriptive study that includes 41 patients with hypospadias who underwent DUCKETT procedure by a tubed pedicled preputial island flap during a period of 12 years. After penile degloving, the curvature has been corrected by skin bridging with or without Nesbit's plication. The urethroplasty was done according to the DUCKETT procedure.

Results: The patients mean age was $11 \pm 8.5$ years. All of them had posterior foreskin and a ventral curvature of the penis. The urethral meatus was posterior in $37 \%$. Six of them had a previous hypospadias repair. The complication rate was $58.5 \%$. Wound infection and meatal stenosis occurred in $14.6 \%$ and $19.6 \%$ of cases, respectively. After a mean follow-up of $20 \pm 9$ months, total success, relative success and failure rates were $63 \%, 27 \%$ and $10 \%$, respectively.
\end{abstract}

Conclusion: The DUCKETT procedure is associated with a high complication rate in our daily practice.

Keywords: Hypospadias, Penile, Curvature, Preputial island flap, Duckett procedure

\section{Background}

Hypospadias is the second most frequent congenital condition in boys after cryptorchidism, with an incidence of $0.3-0.7 \%$ compared to $2-4 \%$ for cryptorchidism [1]. Surgery should be offered for all forms of hypospadias, but there is no consensus on the minimum age for the surgery. The results of this surgery pose a problem because of its many complications. Since the 1980s, single-stage

*Correspondence: ndiaymodou87@gmail.com

1 Service d'urologie CHU Dalal Jamm, Dakar, Sénégal

Full list of author information is available at the end of the article operations, such as the one described by DUCKETT [2], have been adopted by some authors [3]. Surgery for hypospadias can be done in one or more operative stages. Each technique has its own advantages, but one-stage procedures are often associated with complications and require reoperations [4]. The complication rates were $20 \%-50 \%$ [4]. The debate over the optimal treatment for hypospadias is ongoing and most believe that a twostage procedure offers superior functional and cosmetic results with fewer complications like the Bracka technique. These procedures seem to be more adapted in our developing countries where the cost of surgery remains 
inaccessible to the majority of the patients. A few studies have evaluated the results of DUCKETT's procedure for hypospadias in our countries. The aim of this work was to evaluate the results of DUCKETT's pedicled prepucial flap procedure for hypospadias treatment in a reference hospital in West Africa.

\section{Methods}

This is a retrospective study of all hypospadias patients treated by the DUCKETT technique from January, 1st 2003 to December, 31st 2015. The patients were operated on by senior surgeons.

\subsection{Surgical technique}

All children were operated on under general anesthesia and the adults under spinal anesthesia. Antibiotic prophylaxis was systematic. The correction of the curvature started with an undressing of the penis, then resection of the fibrous tissues and an excision of the urethral plate. If necessary, a plication of the tunica albuginea on the opposite side to the curvature was carried out according to Nesbit [5]. Urethroplasty consisted in tubularizing a pedicled prepucial flap according to the DUCKETT technique [2]. A muco-cutaneous, transverse and posterior flap of the prepuce was kept integral with its subcutaneous tissue. Thus pedicled flap, was tubularized and tilted longitudinally anteriorly to form the missing urethral canal. The lower end was anastomosed to the hypospadic urethra, while the upper end created the new urethral meatus. This tubular flap was fixed in an orthotopic position at points, which were separated. As the meatus was to terminate at the top of the glans, the tube was tunneled distally to the glans before being anastomosed to the mucous membrane of the glans. One to two additional layers are placed on the neo-urethra, one of which constitutes the spongioplasty. The Duplay technique was associated with this in some patients. This consists in tubularizing the urethral plate on itself from the ectopic orifice to the top of the glans after an incision on either side of it. This association is made in the very posterior forms to reduce the length of the foreskin used. Slowly absorbable sutures (PDS ${ }^{\mathrm{TM}}$, Ethicon Inc., Johnson \& Johnson, Issy-les-Moulineaux, France) were used ( $4 / 0$ or $5 / 0$ in children, and 3/0 or $4 / 0$ in adults). Figure 1 shows the different stages of the technique used. The duration of post-operative trans-urethral drainage was 10 days.

\subsection{Evaluation of results}

The occurrence of post-operative complications and the clinical results at the last check-up were evaluated. We defined total success as an apical meatus, a straight penis and a cosmetic aspect deemed satisfactory by the surgeon. Relative success was defined by the need for maintenance dilatations, the existence of residual curvature, or a poor cosmetic result considered by the surgeon. Failure was defined as total suture release and urethral stenosis without success at revision surgery. Unsatisfactory cosmetic appearance corresponded to unsightly healing of the penis. The acceptable residual curvature was defined as a curvature of less than $20^{\circ}$ without a painful erection. Data entry and statistical analysis were carried out using Excel 2007 software (Microscoft, Redmond, WA, USA).

\section{Results}

Forty-one patients were included in our study with a mean age of $11 \pm 8.5$ years (extremes of 1.8 and 31 years). Hypospadias was anterior in 14 cases (34\%), middle in 12 cases (29\%), and posterior in 15 cases (36\%). All patients had a ventral curvature of the penis. All patients selected for this technique had a posterior preputial apron. Six patients (14.6\%) had a recurrent hypospadias. Excision of fibrous tissue with loosening of the penis associated with excision of the urethral plate was sufficient in 25 cases $(61 \%)$ to correct the curvature. A plication of the tunica albuginea of corpora cavernosa was needed in 16 cases (39\%). A Duplay procedure was added to the Duckett procedure in three patients (7.3\%). Twenty-four patients (58.5\%) had a complication. A wound infection and a neo-meatus stenosis were the most frequent complications (Table 1). Only seven patients were reoperated with a surgical revision rate of $17 \%$. The three cases of total suture loosening had revision surgery 3 to 6 months later with only one case of success. The case of urethrocutaneous fistula had a successful repair by excision of the fistulous tract and closure of the defect using interrupted sutures of the urethral and cutaneous planes. The six cases of meatus stenosis were treated by iterative dilation using HEGAR candles with satisfactory results. The two cases of proximal urethral stenosis were treated unsuccessfully with urethroplasty. The case of retraction of the neo-meatus was treated with an additional repair, according to Duplay alongside with a meatoplasty with a satisfactory evolution. Non-troublesome residual curvature and poor cosmetic results were simply monitored. At the last follow-up of $20 \pm 9$ months, the rates of total success, relative success and failure were $63 \%$ (26 cases), $27 \%$ (11 cases) and $10 \%$ ( 4 cases), respectively, after treatment of complications.

\section{Discussion}

Surgery is the standard treatment for hypospadias. It is a difficult surgery, with a multitude of techniques described. The posterior forms of hypospadias require the most complex techniques with a higher risk of complications [6. To improve the results, some authors opt 


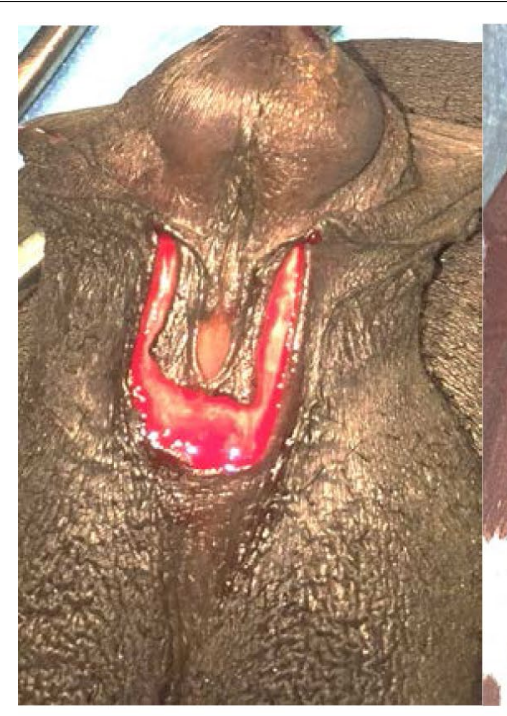

A

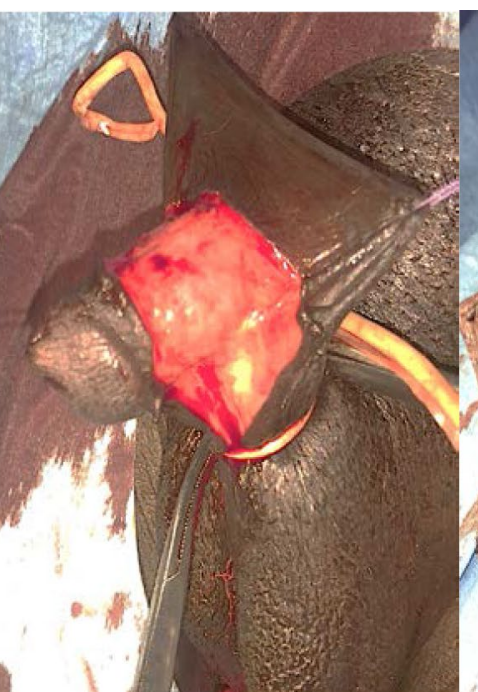

B

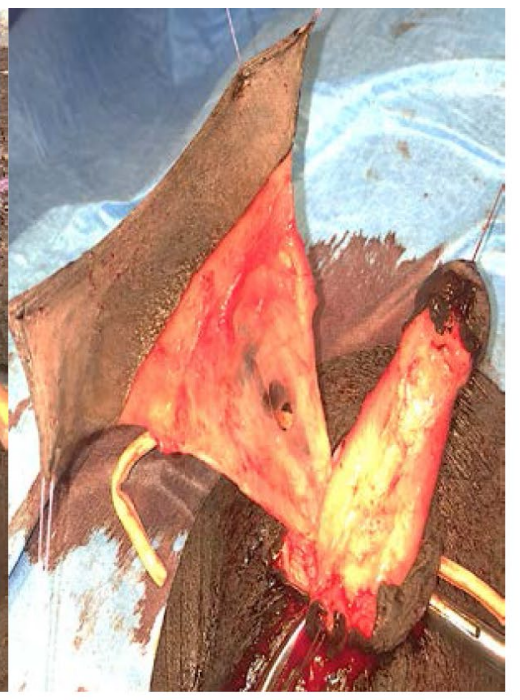

C
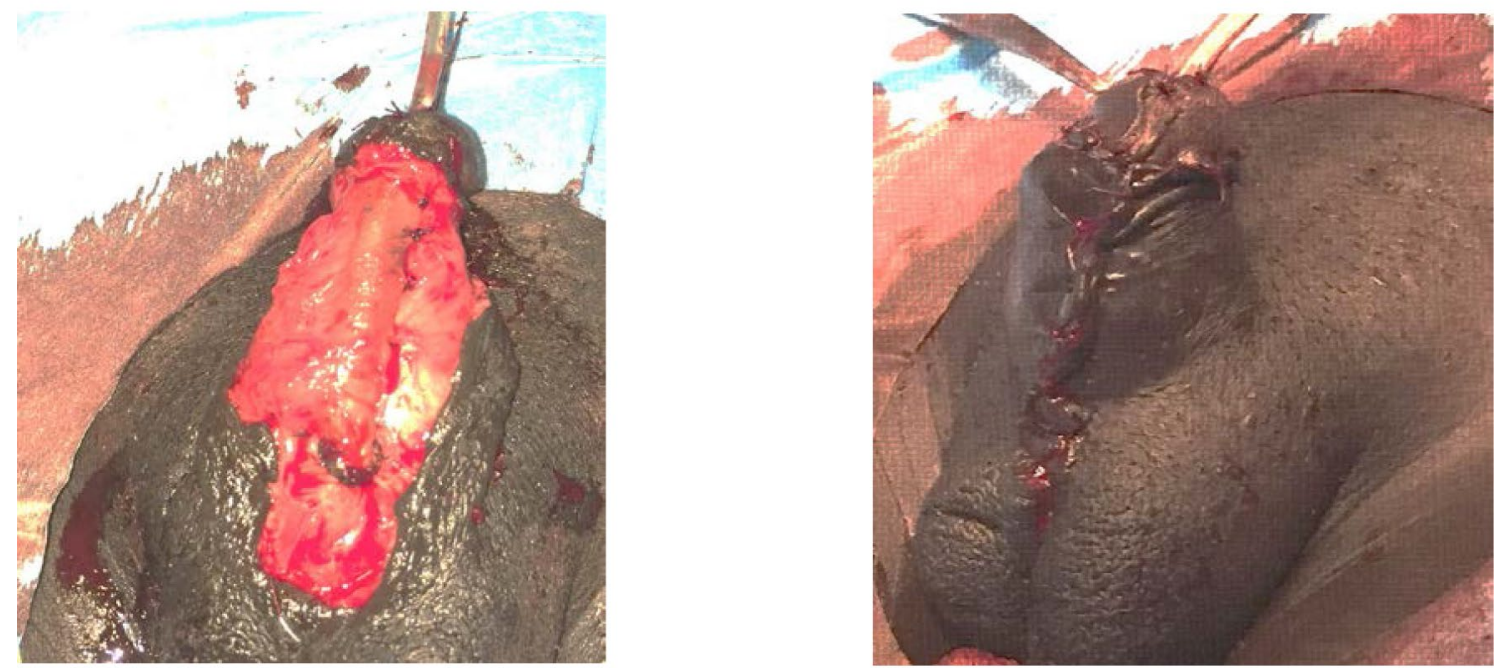

\section{D}

Fig. 1 A Inverted U-shaped incision circumscribing the hypospade urethral meatus. B Penile degloving, excision of the fibrous tissue, and raising of the prepucial flap. C Rotation of the preputial pedicled flap after section of the urethral plate. D Tubulation of the preputial flap pedicled around a urinary catheter with meatoplasty and suture of the proximal end to the urethral tracheus. E Final appearance after skin closure

for two-stage techniques $[3,7]$. These would reduce the rate of infection and failure due to flap necrosis or suture disunion [3]. Zheng et al. [7] recommend two-stage urethroplasty in posterior forms with severe curvature after excision of the urethral plate, because they believe that this avoids the frequent urethral stenosis that occurs with single-stage urethroplasty. Bankole Sapin et al. [3] found a complication rate of $26 \%$ for two-stage surgery and $37 \%$ for one-stage surgery. However, the anesthetic risk and the additional financial costs generated by this technique are not negligible [8]. The Bracka technique is the most successful in this indication [8]. The choice of the DUCKETT's one-step technique [2] in our series was guided by the need to excise the urethral plate as part of the orthoplasty, the presence of a posterior preputial apron, but also because of the good mastery of the technique 
Table 1 Distribution according to the different complications

\begin{tabular}{llc}
\hline Complications & $\begin{array}{l}\text { Effective } \\
\text { (number of } \\
\text { cases) }\end{array}$ & Frequency (\%) \\
\hline Superinfection of the wound & 6 & 14.6 \\
Complete suture release & 3 & 7.3 \\
Urethro-cutaneous fistula & 1 & 2.4 \\
Retraction of the neo-meatus & 1 & 2.4 \\
Stenosis of the neo-meatus & 6 & 14.6 \\
Urethral stenosis & 2 & 4.9 \\
Residual curvature & 2 & 4.9 \\
Bad cosmetic result & 3 & 7.3 \\
Total & $\mathbf{2 4}$ & $\mathbf{5 8 . 5}$ \\
\hline
\end{tabular}

in our center. Added to this, the financial reasons and the problem of follow-up. For some authors [9], singlestage urethroplasty offers good results, especially for very young patients. While others, such as Bankole Sapin R et al. [3], believe that it is more likely to have complications. Complications of hypospadias surgery are particularly common in developing countries [3, 10]. Several factors may explain this phenomenon: the unavailability of adequate equipment (magnifying glasses, fine threads and microsurgical instruments in particular), the problem of post-operative care often entrusted to non-specialist nurses and the variability of the operators. Lower complication rates are noted by other authors, especially in Western countries $[6,11]$. The main complications of hypospadias surgery reported in the literature are wound infection, flap necrosis, urethro-cutaneous fistula, and neo-urethral or neo-meatus stenosis [3, 10-13]. Wound infection was the most common early complication in this series, probably due to the poor conditions in which post-operative care was carried out, but also due to the hot and dry tropical climate. The use of two-stage surgery could in some cases minimize this complication rate. These infections are promoted to the failure of the repair by the sutures being loosened or by flap necrosis [14]. Flap necrosis can also be the consequence of poor dissection and devascularisation of the flap. Diallo et al. [10] reported $15 \%$ flap necrosis and suture disunion. No cases of flap necrosis were reported in this series. Urethrocutaneous fistula was present in $2.4 \%$ of the cases in our series. Other authors reported varying frequencies ranging from $7.9 \%$ to $25 \%$ of cases depending on the series $[3,10,11]$. Prevention of this fistula can be achieved by interposing a secondary layer between the flap and the skin [15]. It is advisable to put in intermediate layers to minimize the risk of fistula [16]. The low rate of fistulas in this series may be due to this procedure being performed in most patients. The secondary treatment of this fistula is usually easy, but there is a risk of failure depending on the size of the fistula, the number of fistulas and the experience of the surgeon [14]. However, the age of the fistula, its location, and the length of the neo-urethra do not seem to influence the results [14]. Urethral stenosis is usually the result of devascularization of the stenotic area in the case of tension anastomosis, with a higher risk of wound infection [10]. The urethral stenosis rate is variable according to the literature. The rate was high in the series of Akbiyik et al. [12] who reported a 27.5\% stenosis rate, while Mosharafa et al. [6] reported only $0.9 \%$ urethral meatus stenosis. Finally, the rate of unintrusive residual penile curvature (5\%) was lower than that reported by Diallo et al. [10]. In total, the success rate of the DUCKETT technique was $63 \%$ after treatment of complications. The rate of good results depends, among other things, on the technique, the operator's experience, the type of hypospadias, and the presence and severity of the curvature [16]. Diallo et al. [10] in Guinea, after a 3-22 month follow-up, reported $61.7 \%$ good results for all techniques and all forms of hypospadias. While Diao et al. [13] in Senegal reported $62.5 \%$ good results for all previous forms of hypospadias, all techniques combined. Other, mainly western authors such as Dewan et al. [17] report better success rates with the Duckett technique after a single treatment $(66.6 \%$ success rate out of 190 hypospadias treated). Similarly, Zheng et al. [15] reported only $24 \%$ complications after a first treatment with a pedicled preputial flap. According to them, the failure rate is higher with the Duckett procedure for recurrent hypospadias. The poor prognosis risk factors were advanced age at the time of surgery, the absence of an additional layer, and tissue fibrosis [15]. Lyu et al. [18], comparing the tubulated Duckett preputial flap with the untubulated Onlay patch flap, noted a higher rate of fistulas and stenosis with the DUCKETT procedure.

\section{Conclusion}

In our care context, the treatment of hypospadias with the DUCKETT technique gives encouraging results, but with a high complication rate. It is a complex surgery carried out in non-optimal conditions. Wound infection is a major problem. It is, therefore, necessary to improve aseptic conditions in the operating theater and during post-operative care, but also to train urologists in this specialized surgery.

\section{List of Abbreviation}

PDS: Polydioxanone synthetic.

\section{Acknowledgments}

We thank all the urology staff of the University Hospital Aristide Le Dantec in Dakar. 


\section{Authors' contributions}

$M N, Y S, A S$, and AmT: data collection, article writing, validation of the version to be published. STF, NSN, BS, CZ-O, NAB, OS, AN, AbT, BF, BD, PAF, and AKN: data collection and patient care. All authors have read and approved the manuscript.

\section{Funding}

It is no source of funding.

\section{Availability of data and materials}

The datasets used and/or analyzed during the current study are available from the corresponding author.

\section{Declarations}

\section{Ethics approval and consent to participate}

This study was approved by the ethics committee of Hospital Aristide Le Dantec of Dakar, Senegal. This committee is made up of the head of the department and the other urology teachers. If the reference number is not applicable. Since it was a retroscopic review, consent was not required.

\section{Consent for publication}

Not applicable.

\section{Competing interests}

The authors declare that they have no conflict of interest.

\section{Author details}

'Service d'urologie CHU Dalal Jamm, Dakar, Sénégal. ²Service d'urologie CHU Aristide Le Dantec, Dakar, Sénégal. ${ }^{3}$ Service d'urologie Hôpital Principal de Dakar, Dakar, Sénégal. ${ }^{4}$ Service d'urologie Hôpital militaire de Ouakam, Dakar Sénégal. ${ }^{5}$ Service d'urologie Hôpital de la Paix de Chiguinchor, Chiguinchor, Sénégal.

Received: 30 June 2021 Accepted: 16 November 2021

Published online: 07 December 2021

\section{References}

1. Boudaoud N, Pons M, Bouche Pillon Persyn MA, Lefebvre F, Poli Merol ML, Francois C (2016) Hypospadias. Ann Chir Plast Esthét. 61 (5):439-449

2. Duckett JW (1980) Transverse preputial island flap technique for repair of severe hypospadias. Urol Clin North Am 7(2):423-430

3. Bankole Sapin R, Nandiolo R, Yao B, Tam- bo F, Vodi L, Mobiot L (2007) Le traitement de I'hypospadias posterieur au CHU de Treichville (Abidjan). Prog Urol 17(4):860-862

4. Sadeghi A, Mirshemirani A, Khaleghnejadtabari A, Sadeghian N, Rozroukh M, Ghoroubi J et al (2017) Duckett versus modified Bracka technique for proximal hypospadias repair a 10-year experience. Iran J Pediatr 27(6):e7752

5. Nesbit RM (1965) Congenital curvature of the phallus : report of three cases with description of corrective operation. J Urol 93:230-232

6. Mosharafa AA, Agbo-Panzo D, Priso R, Aubry E, Besson R (2009) Cure d'hypospadias. La forme de la plaque urétrale a-t-elle une influence sur le résultat de l'intervention de Duplay-Snodgrass? Prog Urol 19(7):510-511

7. Zheng DC, Yao HJ, Cai ZK, Da J, Chen Q, Chen YB et al (2015) Two stageurethroplastyis a betterchoicefor proximalhypospadias with chordee after urethralplate transection : a sigle center experience. Asian J Androl 17(1):94-97

8. Bhat A, Single M, Bhat M, Sabharwal K, Upadhay R, Kumar V (2015) Incised plate uretroplasty in perinéal and périnéo-scrotal hypospadias. Afr J Urol 21:105-110

9. Moudouni S, Tazi K, Nouri M, Koutani A, Hachimi M, Lakrissa A (2001) Hypospadias in adults. Prog Urol 11(4):667-669

10. Diallo AB, Bah I, Toure BM, Ouendeno LB, Balde I, Diallo MB (2008) L'hypospadias: aspects anatomo-cliniques et thérapeutiques au CHU de Conakry Guinée. Andrologie 18(2):131
11. Spinoit AF, Poelaert F, Groen LA, Van Laecke E, Hoebeke P (2013) Hypospadias repair at a tertiary care center: long-term followup is mandatory to determine the real complication rate. J Urol 189(6):2276-2281

12. Akbiyik F, Tiryaki T, Şenel E, Mambet E, Livanelioglu Z, Atayurt H (2009) Clinical experience in hypospadias: results of tubularized incised plate in 496 patients. Urology 73(6):1255-1257

13. Diao B, Fall PA, Ndoye AK, Diallo Y, Sow Y, Diabaté I et al (2006) Anterior hypospadias: one stage repair. Report of 40 cases. Dakar Med 51(3):151-154

14. Han W, Zhang W, Sun N (2018) Risk factors for failed urethrocutaneous fistula repair after transverse prepucial island flap urethroplasty. Int Urol Nephrol 50(2):191-195

15. Zheng DC, Wang H, Lu MJ, Chen Q, Chen YB, Ren XM et al (2013) Acomparative study of the use ofa transverse preputial island flap (the Duckett technique)to treat primary and secondary hypospadias in older chinese patients with severe chordee. World J Urol 31(4):965-969

16. Cheng EY, Vemulapalli SN, Kropp BP, Pope JC, Furness PD, Kaplan WE, Smith DP (2002) Snodgrass hypospadias repair with vascuralized Dartos flap : the perfectrepairfor virgin cases of hypospadias. J urol 4(2):1723-1726

17. Dewan PA, Dinneen MD, Winkle D, Duffy PG, Ransley PG (1991) Hypospadias : Duckett Pedicle Tube Urethroplasty. Eur Urol 20:39-42

18. Lyu Y, Yu L, Xie H, Huang Y, Li X, Sun L et al (2019) Comparison of shortterm complications between Onlay and Duckett urethroplasty and the analysis of risk factors. Int Urol Nephrol 51(5):783-788

\section{Publisher's Note}

Springer Nature remains neutral with regard to jurisdictional claims in published maps and institutional affiliations.

\section{Submit your manuscript to a SpringerOpen ${ }^{\circ}$ journal and benefit from:}

- Convenient online submission

- Rigorous peer review

- Open access: articles freely available online

- High visibility within the field

- Retaining the copyright to your article

Submit your next manuscript at $\boldsymbol{\nabla}$ springeropen.com 